\title{
A Study of Anatomical Shape of arch projected by Alveolar Process of Maxillary and Mandibular Bone
}

\author{
Prakash Baral*, Rami Shrestha, Subash Sapkota, Sapana Koju and Binod Chaudhari \\ Department of Anatomy, Gandaki Medical College, Kaski, Nepal
}

\begin{abstract}
Introduction: Maxilla and Mandible have an alveolar process that bears socket for root of teeth. When the teeth fall or gets extracted there is resorption of alveolar process. The teeth alignment determines the shape of alveolar process. The objectives of the study was to assess the distribution pattern of anatomical shape of arch projected by alveolar process in Maxilla and Mandible and to compare the anatomy of arch amongst the population of Aryan and Mongoloid communities. Methodology: A total number of 856 people with intact anatomy of alveolar arch were included in the study. Anatomy of alveolar arches were assessed and noted for all. The brass wire was contoured according the shape of alveolar arch of patients and the shape was observed and noted down. Result: The study result showed there was significant difference in frequency distribution of ' $U$ ', ' $V$ ' and 'Ovoid' shape alveolar arch form in maxilla and mandible. There was significant difference in distribution of ' $U$ ' and ' $V$ ' shape alveolar arch form in maxilla and ' $U$ ', ' $V$ ' and 'Ovoid' shape arch form in mandible between mongoloid and Aryan communities. Conclusion: 'U'shape alveolar arch was seen more frequently in mandible where as " $\mathrm{V}$ " shape and 'Ovoid' shape arch in maxilla. ' $U$ ' shape alveolar arch was more frequently seen in Mongoloid communities and ' $\mathrm{V}$ ' shape was more frequently seen in Aryan communities. There was no significant difference in comparison of frequency percentage of various types of arch form between the Male and Female.
\end{abstract}

Key words: Anatomy of alveolar arch, Aryan, Mongoloid

\section{Correspondence to:}

Dr. Prakash Baral

Professor

Anatomy Department, Gandaki Medical College,

Kaski, Nepal

E-mail: prakashbaral2002@gmail.com

Submitted: July 22, 2020

Accepted: November 20, 2020

To cite: Baral P, Shrestha R, Sapkota S, Koju S, Chaudhari B. A Study of Anatomical Shape of arch projected by Alveolar Process of Maxillary and Mandibular Bone. JGMC Nepal. 2020;13(2):164-8.

DOI: 10.3126/jgmcn.v13i2.30222

\section{INTRODUCTION}

The alveolar process is that part of maxilla and mandible that forms and supports the sockets of teeth. The roots of teeth are suspended in the socket by the attachment of periodontal ligament. The joint between the alveolar socket and the root of teeth is called 'Gomphosis' which is fibrous joint. The alveolar bone is a projection from basal part of jaw to accommodate the roots of teeth. That is why it is called alveolar process. The curvilinear alignment of teeth confirms the anatomical shape of alveolar process which is known as 'alveolar arch'. Anatomy of alveolar arch deals with morphology of alveolar arch in terms of shape. It is an anthropometric study as the study is exploring the distribution of anatomical form of alveolar arch in population. The basic pattern of tooth position in the arch is the alveolar arch form. The curving structures are formed by a line described by the buccal surfaces or through the central grooves of the molars and bicuspids of the teeth in their normal position viewed from the incisal and occlusal aspect. The maxillary teeth are positioned on the maxilla, as are the mandibular teeth on the mandible in such a way as 
to produce a curved "arch" when viewed from the occlusal surface. ${ }^{1}$

Anthropometrically anatomy of face and anatomy of alveolar arch can be related. Square or U-shape alveolar arch can be seen in brachy-facial people, tapered or V-shape in dolichofacial where as elliptical or ovoid shape is seen in meso-facial people. It is the gene of an individual that determines the anatomy of his/her alveolar arch and facial form.

Rationale of the present study: There is no anthropometric study on anatomy of alveolar arch in population so far. Nepalese as well as global data banking is very poor on the subject thus the present study has been undertaken so as to contribute the Nepalese data base.

Importance of present study: Knowledge of alveolar arch forms present among Nepalese population will be useful for anatomists, forensic experts, anthropologists, orthodontists, prosthodontists, and manufacturer of orthodontic appliances. This information will not only highlight the pattern of various alveolar arch forms but also will enable researchers to work and explore the further opportunity in this field. The study will help develop strategies for control of abnormal arches, planning the treatment and implementation of preventive dento-facial orthopedic programmes.

\section{OBJECTIVES}

General Objective of Study: To Study of Anatomical Shape of arch projected by Alveolar Process of Maxillary and Mandibular Bone.

\section{Specific objectives of study:}

1. To assess the distribution pattern of anatomical shape of arch projected by alveolar process in Maxilla and Mandible.

2. To compare the anatomy of arch projected by alveolar process amongst the population of Aryan and Mongoloid communities.

3. To compare the anatomy of arch projected by alveolar process sex wise.

\section{METHODS}

The study was conducted in Kaski district of Nepal from December 2013 to May 2019. It was a cross-sectional study. Convenient non-probability sampling technique was adopted. All people coming to the health camps were studied. The study was conducted at health camps at various places of Kaski District like Tarkang, Bhadaure, Riwan, Ghachowk, Armala, Lwang Ghalel, Ghandruk, Dhampus, Taprang and Siklesh village development committees at various period of time from December 2013 to May 2019.
It included various communities of Aryan and Mongoloid communities (like Brahmin and Chhetri belonging to Aryan communities as well as Gurung and Magar belonging to Mongoloid communities). A total number of 1000 people of those communities were included in the study, out of which 143 subjects were excluded because they could not meet the inclusion criteria. Thus, total valid sample number was 857 .

\section{Inclusion criteria}

All the measurements for this study were collected from people having intact anatomy of alveolar arch from Aryan and Mongoloid communities like Brahmin, Chhetri, Gurung and Magar communities residing in Kaski district of Nepal. Such people were with history of no teeth extractions and without severe decay of teeth. There was possibility of mixing of genes in persons born to parents who had intercast marriage and such mixed gene results imperfect characters for specific community in anthropology thus they were avoided in study.

Exclusion criteria: People with growth disorders or having trauma on facial region or belonging to intermingling communities (i.e. people whose parents and grand- parents had inter-cast marriage) were excluded. People with history of teeth extractions and with severe decayed of teeth were also excluded as such conditions affect the anatomy of alveolar arch.

Reliability and validity of research: Adequate sample size, adaptation of proper research methodology, due care given during data collection and entry, correct use of statistical tests etc enhanced the reliability and validity of present study. For the sake of good reliability and validity of research, single observer assessed the anatomy of alveolar arch in all subjects.

Evaluation of alveolar arch form: The brass wire was contoured according the shape of alveolar arch of patients into the oral cavity and the shape of brass wire was observed and noted down. (figures 1, 2, and 3)

Instruments and Materials: The brass wires were used. They were highly flexible and easily can be contoured according to shape of alveolar arch.

\section{Some operational definitions used in present research study are:}

Alveolar arch: It is the arch projected by alveolar process of maxillary and mandibular bone. Shape of alveolar arch: It is the morphological contour of alveolar arch. Statistical design and analysis

The collected data was entered into computer using microsoft windows' access software and after purification of data, 
analysis was done into SPSS (Statistical Package for Social Sciences) version 16: 00 software. Frequency, proportion and percentage was calculated to summarize the collected information. "Chi-square" statistical tests were used to test the significance of the variables depending upon the nature of data collected. Evidence based conclusions were drawn from the study-based results. For the data quality control during present research study, measures taken were adopting correct method of data collection; screening and verifying the collected data; selecting appropriate computer software; coding and entering the data into computer and recheck it; processing the data; constructing a data base for data management and appropriate data analysis and review over it.

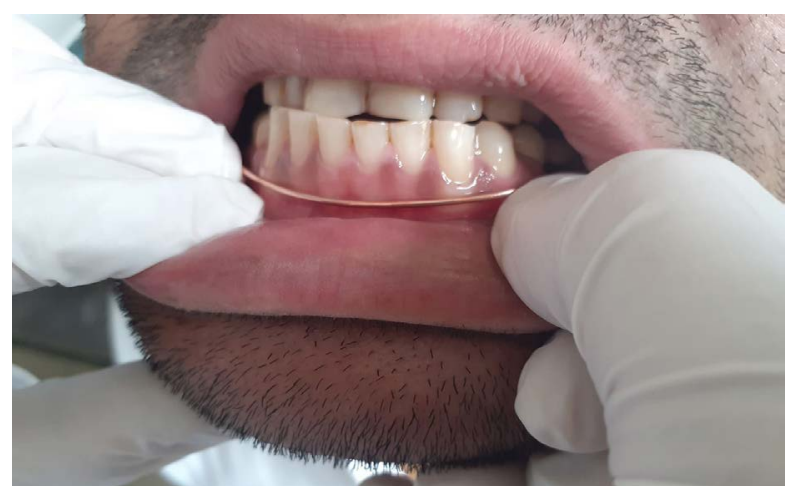

Figure 1: Contouring brass wire according to shape of alveolar arch of mandibular bone.



Figure 2: Contouring brass wire according to shape of alveolar arch of maxillary bone.

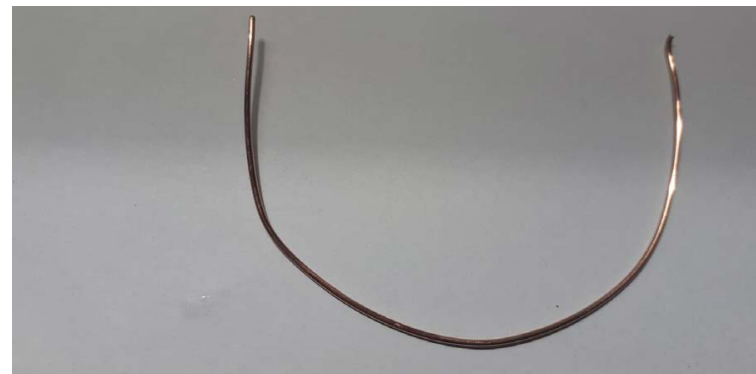

Figure 3: Contoured brass wire according to shape of alveolar arch

\section{RESULT}

One thousand subjects were studied for this study. Out of which 143 subjects were excluded because they could not meet the inclusion criteria. Thus, total valid sample number was 857. The sex, age, and community wise distribution is given in Table 1 and Table 2. Table 3 shows there was significant difference in frequency distribution of ' $U$ ', ' $V$ 'and 'Ovoid' shape alveolar arch form in maxilla and mandible. ' $U$ ' shape alveolar arch was seen more frequently in mandible where as "V" shape and 'Ovoid' shape arch in maxilla. Table 4 shows the frequency percentage of various types of arch form in various communities ( $\mathrm{n}=857$ ).

Table 5 reveals there was significant difference in distribution of ' $U$ ' and ' $V$ ' shape alveolar arch form in maxilla and in mandible between Mongoloid (Gurung and Magar) and Aryan (Brahmin and Chhetri) communities. ' $U$ ' shape alveolar arch was more frequently seen in Mongoloid communities and ' $\mathrm{V}$ ' shape was more frequently seen in Aryan communities. Table 6 shows there was no significant difference in comparison of frequency percentage of various types of arch form between the Male and Female.

Table 1: Distribution of valid subjects sex wise:

\begin{tabular}{ll}
\hline Sex & Frequency $(\%)$ \\
Male & $429(50.05)$ \\
Female & $428(49.95)$ \\
Total & $857(100)$ \\
\hline
\end{tabular}

Table 2: Distribution of valid subjects community wise:

\begin{tabular}{lll}
\hline Communities & Communities & Frequency (\%) \\
Aryan race $(\mathbf{n}=425)$ & Brahmin & $201(23.4)$ \\
& Chhetri & $224(26.2)$ \\
Mongolian race $(\mathrm{n}=432)$ & Magar & $208(24.2)$ \\
& Gurung & $224(26.2)$ \\
& Total & $857(100)$ \\
\hline
\end{tabular}

Table 3: Comparison of frequency distribution of types of alveolar arch form in the population $(n=857)$

\begin{tabular}{llll}
\hline Arch & "U" & "V" & "Ovoid" \\
$\begin{array}{llll}\text { Upper or Maxillary alveolar } \\
\text { arch }\end{array}$ & $\begin{array}{l}19 \% \\
(n=163)\end{array}$ & $\begin{array}{l}23 \% \\
(n=197)\end{array}$ & $\begin{array}{l}58 \% \\
(n=497)\end{array}$ \\
$\begin{array}{llll}\text { Lower or Mandibular alveolar } \\
\text { arch }\end{array}$ & $\begin{array}{l}60 \% \\
(n=514)\end{array}$ & $\begin{array}{l}10 \% \\
(n=86)\end{array}$ & $\begin{array}{l}30 \% \\
(n=257)\end{array}$ \\
P value & 0.01 & 0.04 & 0.03 \\
\hline
\end{tabular}

(Statistically significant, $\mathrm{p}<0.05$ ) 
Table 4: Frequency percentage of various types of arch form in the various communities: $(n=857)$

\begin{tabular}{|c|c|c|c|c|c|}
\hline & Arch types & Brahmin & Chhetri & Magar & Gurung \\
\hline \multirow{3}{*}{$\begin{array}{l}\text { Upper or Maxillary } \\
\text { alveolar arch }\end{array}$} & "U" & $\begin{array}{l}12 \% \\
(n=24)\end{array}$ & $\begin{array}{l}11.5 \% \\
(n=26)\end{array}$ & $\begin{array}{l}31.5 \% \\
(n=66)\end{array}$ & $\begin{array}{l}33 \% \\
(n=74)\end{array}$ \\
\hline & "V" & $\begin{array}{l}28.5 \% \\
(n=57)\end{array}$ & $\begin{array}{l}28.5 \% \\
(n=64)\end{array}$ & $\begin{array}{l}13.5 \% \\
(n=28)\end{array}$ & $\begin{array}{l}12.5 \% \\
(n=28)\end{array}$ \\
\hline & "Ovoid" & $\begin{array}{l}59.5 \% \\
(n=120)\end{array}$ & $\begin{array}{l}60 \% \\
(n=134)\end{array}$ & $\begin{array}{l}55 \% \\
(n=114)\end{array}$ & $\begin{array}{l}54.5 \% \\
(n=122\end{array}$ \\
\hline \multirow{3}{*}{$\begin{array}{l}\text { Lower or } \\
\text { Mandibular } \\
\text { alveolar arch }\end{array}$} & "U" & $\begin{array}{l}52 \% \\
(n=104)\end{array}$ & $\begin{array}{l}49.4 \% \\
(n=110)\end{array}$ & $\begin{array}{l}78.6 \% \\
(n=163)\end{array}$ & $\begin{array}{l}78.3 \% \\
(n=175)\end{array}$ \\
\hline & "V" & $\begin{array}{l}29.3 \% \\
(n=59)\end{array}$ & $\begin{array}{l}32 \% \\
(n=72)\end{array}$ & $\begin{array}{l}8.2 \% \\
(n=18)\end{array}$ & $\begin{array}{l}11 \% \\
(n=25)\end{array}$ \\
\hline & "Ovoid" & $\begin{array}{l}18.7 \% \\
(n=38)\end{array}$ & $\begin{array}{l}18.6 \% \\
(n=42)\end{array}$ & $\begin{array}{l}13.2 \% \\
(n=27)\end{array}$ & $\begin{array}{l}10.7 \% \\
(n=24)\end{array}$ \\
\hline
\end{tabular}

Table 5: Comparison of frequency percentage of various types of arch form in between the Aryan and Mongoloid communities: $(\mathrm{n}=857)$

\begin{tabular}{|c|c|c|c|c|}
\hline & Arch types & Aryan $(n=425)$ & $\begin{array}{l}\text { Mongoloid } \\
(\mathrm{n}=\mathbf{4 3 2})\end{array}$ & P value \\
\hline \multirow{3}{*}{$\begin{array}{l}\text { Upper or } \\
\text { Maxillary } \\
\text { alveolar arch }\end{array}$} & "U" & $\begin{array}{l}11.7 \% \\
(\mathrm{n}=50)\end{array}$ & $\begin{array}{l}32.4 \% \\
(\mathrm{n}=140)\end{array}$ & 0.03 \\
\hline & "V" & $\begin{array}{l}28.4 \% \\
(\mathrm{n}=121)\end{array}$ & $\begin{array}{l}13 \% \\
(\mathrm{n}=56)\end{array}$ & 0.04 \\
\hline & "Ovoid" & $\begin{array}{l}59.7 \% \\
(\mathrm{n}=254)\end{array}$ & $\begin{array}{l}54.6 \% \\
(\mathrm{n}=236)\end{array}$ & 0.08 \\
\hline \multirow{3}{*}{$\begin{array}{l}\text { Lower or } \\
\text { Mandibular } \\
\text { alveolar arch }\end{array}$} & "U" & $\begin{array}{l}50.3 \% \\
(\mathrm{n}=214)\end{array}$ & $\begin{array}{l}78.2 \% \\
(\mathrm{n}=338)\end{array}$ & 0.02 \\
\hline & "V" & $\begin{array}{l}30.8 \% \\
(\mathrm{n}=131)\end{array}$ & $\begin{array}{l}10 \% \\
(n=43)\end{array}$ & 0.03 \\
\hline & "Ovoid" & $\begin{array}{l}18.8 \% \\
(\mathrm{n}=80)\end{array}$ & $\begin{array}{l}11.8 \% \\
(\mathrm{n}=51)\end{array}$ & 0.07 \\
\hline
\end{tabular}

(statistically significant, $\mathrm{p}<0.05$ )

Table 6: Comparison of frequency percentage of various types of arch form in between the Male and Female:( $n=857)$

\begin{tabular}{|c|c|c|c|c|}
\hline & Arch types & Male $(n=429)$ & $\begin{array}{l}\text { Female } \\
(n=428)\end{array}$ & $P$ value \\
\hline \multirow{3}{*}{$\begin{array}{l}\text { Upper or } \\
\text { Maxillary } \\
\text { alveolar arch }\end{array}$} & "U" & $\begin{array}{l}19.3 \% \\
(n=83)\end{array}$ & $\begin{array}{l}18.6 \% \\
(n=80)\end{array}$ & 0.09 \\
\hline & "V" & $\begin{array}{l}22.6 \% \\
(n=97)\end{array}$ & $\begin{array}{l}23.3 \% \\
(n=100)\end{array}$ & 0.09 \\
\hline & "Ovoid" & $\begin{array}{l}58.0 \% \\
(n=249)\end{array}$ & $\begin{array}{l}57.9 \% \\
(n=248)\end{array}$ & 1.00 \\
\hline \multirow{3}{*}{$\begin{array}{l}\text { Lower or } \\
\text { Mandibular } \\
\text { alveolar arch }\end{array}$} & "U" & $\begin{array}{l}59.6 \% \\
(n=256)\end{array}$ & $\begin{array}{l}60.2 \% \\
(n=258)\end{array}$ & 0.09 \\
\hline & "V" & $\begin{array}{l}10.7 \% \\
(n=46)\end{array}$ & $\begin{array}{l}9.3 \% \\
(n=40)\end{array}$ & 0.08 \\
\hline & "Ovoid" & $\begin{array}{l}29.6 \% \\
(n=127)\end{array}$ & $\begin{array}{l}30.3 \% \\
(n=130)\end{array}$ & 0.09 \\
\hline
\end{tabular}

(Statistically significant, $\mathrm{p}<0.05$ )

\section{DISCUSSION}

There is great variation among human alveolar arch form. A persistent search for the ideal arch form is still going on. There has been a different technique for its individualization. However, there is still no characteristic forms for the human alveolar arch. ${ }^{2}$ Different investigators have classified the alveolar arch shape in different way such as: Nakatsuka M et al. classified as round, round-V, round square, square-shaped arches. ${ }^{3}$ But Nojima et al. ${ }^{4}$ classified alveolar arch shape as square, ovoid and tapered. In this study it was observed that $60 \%$ of the upper arch were ovoid, $22.5 \%$ "V" shape, $17.5 \%$ "U" shape while in the lower arch, 62.5\% were "U"shape, $25 \%$ were ovoid and $12.5 \%$ were "V" shape. Izard found the distribution of alveolar arch as ellipse $75 \%$, parabola $20 \%$, U-square shape $5 \%$. He also noticed that maxilla was more elliptical and mandible was parabolic. ${ }^{5}$ De Castro LA et al. ${ }^{6}$ observed that in maxilla, $68.6 \%$ was round upper arch and $31.4 \%$ was triangular upper arch was $31.4 \%$ but in mandible, U shape lower arch was $92 \%$ and square shape lower arch was $8 \%$. However there are other factors also which influence the alveolar arch shape like thumb sucking, tongue thrusting which results in narrow-V shaped maxillary alveolar arch. Subjects having conditions like obstructive sleep apnea also have narrower more tapered and shorter maxillary alveolar arch. Facial form also determines the alveolar arch form like dolico_cephalic person has long narrow face and narrow alveolar arch while brachycephalic person has broad short face and broad round alveolar arch and mesocephalic person has average face with parabolic alveolar arch form.

There was also racial variation in distribution of alveolar arch form as revealed by present study, There was significant difference in distribution of ' $U$ ' and ' $V$ ' shape alveolar arch form in maxilla and $U$ ', 'V' and Ovoid shape alveolar arch form in mandible between mongoloid and Aryan communities. ' $U$ ' shape alveolar arch was more frequently seen in Mongoloid communities and ' $\mathrm{V}$ ' shape was more frequently seen in Aryan communities. There was no significant difference in distribution of various types of arch form between the Male and Female. This finding is significant for anthropologists and forensic experts.

\section{LIMITATIONS OF STUDY:}

The study was conducted only in kaski district with sample size of eight hundred and fifty seven which may not represent entire population. Such type of studies should be carried out in various places and meta-analysis of all those studies should be done in future.

\section{CONCLUSION}

There was significant difference in frequency distribution 
of 'U','V'and 'Ovoid'shape alveolar arch form in maxilla and mandible. 'U'shape alveolar arch was seen more frequently in mandible where as "V" shape and 'Ovoid' shape arch in maxilla. There was significant difference in distribution of ' $U$ ' and ' $V$ ' shape alveolar arch form in maxilla and in mandible between Mongoloid and Aryan communities. ' $U$ ' shape alveolar arch was more frequently seen in Mongoloid communities and ' $\mathrm{V}$ ' shape was more frequently seen in Aryan communities. There was no significant difference in comparison of frequency percentage of various types of arch form between the Male and Female.

\section{Conflict of interest: None}

\section{REFERENCES}

1. Nelson SJ, Ash MM JR, Wheeler's Alveolar Anatomy, physiology and occlusion $7^{\text {th }}$ edition. Bangalore, Prism books Pvt. Ltd, 1993:418-19.

2. Amm EW, Bou-serhal JP. The form of alveolararch according to the Tweed -Merrifield Philosophy; individualization and attempt at standardization.
Orthod Fr.2003 Dec;74(4):481-98. DOI: 10.1051/ orthodfr/200374481 PMID:15301362.

3. Nakatsuka M, Twai Y, Jue SS, Oh SH, Guo L, Tomenaga $\mathrm{Y}$ et al.. Morphological study on the classification of maxillary alveolar arches. Okajimas Folia Anat Jpn. 2004 May; 81(1): 5-13. DOI: 10.2535/ofaj.81.5 PMID:15248560.

4. Nojima K, Mclaughline RP, Isshiki Y, Sinclair PM. A comparative study of Caucasian and Japanese mandibular clinical arch form. Angle Orthod. 2001 Jun; 71(3): 195-200.

5. Graber TM. Orthodontic principle and practice. $3^{\text {rd }}$ edition. Philadelphia: W.B. Saunders company, Delhi :All India traveler book seller;1996:208-211.

6. Decastro LA, Modesto A, Vianna R, Soviero UL. Crosssectional study of the evolution of the primary dentition: Shape of alveolar arches, overjet and overbite. Pesqui Odontol Bras. 2002 Oct-Dec; 16(4): 367-73. DOI: $10.1590 / S 1517-74912002000400015$ PMID: 12612778. 